\title{
ZNACZENIE JEZZYKA W KREOWANIU WIZERUNKU MIASTA
}

\author{
MARTA KOSZKO
}

\begin{abstract}
Cities are the main centres of social, cultural life and economic development. They have always attracted newcomers not only because of new opportunities but also because of the feeling of belonging and uniqueness which people need. The attractiveness of a particular urban centre mainly rests on its image, which is created in relation to its own unique identity. The language of the city, which is present in the public space in the form of the linguistic landscape and which reflects the socio-cultural composition of the city, creates the identity. Both socio-cultural composition of a city (hence the languages spoken in the public space) and the linguistic landscape can create an image of a city which is either open for an interaction or presents limited interactional potential.
\end{abstract}

Key words: city, image, identity, linguistic landscape, interaction

Miasto stanowi obecnie jedną $\mathrm{z}$ głównych przestrzeni codziennej egzystencji, gdyż aż 68\% światowej populacji zamieszkuje tereny miejskie (ONZ, 2018). Poza zaspokajaniem codziennych podstawowych potrzeb człowieka, tj. zapewnieniem schronienia, bezpiecznego miejsca zamieszkania, źródeł utrzymania, które pozwalają na wyżywienie, miasto ma również za zadanie zaspokoić potrzeby społeczne (np. budowanie poczucia wspólnotowości). Jakość miejskiego habitatu wpływa na jakość życia. Wizerunek miasta będzie miał istotny wpływ na to, czy mieszkańcy oraz osoby odwiedzające daną aglomerację poczują się w niej komfortowo, czy będą chciały w niej pozostać czy będą chciały ją poznać. W związku z tym większość dużych ośrodków miejskich inwestuje w odpowiednią promocję danego miejsca, stosując różnego rodzaju zabiegi, które mają na celu podniesienie atrakcyjności danej przestrzeni. Podejmowane działania skupiają się bardzo często na aspektach marketingowych, rzadziej analizuje się inne procesy zachodzące w przestrzeniach miejskich, 
które w mniej bezpośredni i widoczny sposób wpływają na postrzeganie danej aglomeracji. Procesy te związane są między innymi z kształtowaniem interakcyjności danej przestrzeni, czyli, w jaki sposób będzie ona komunikować się ze swoimi użytkownikami. Na interakcyjność przestrzeni wpływają m.in. jej użytkownicy (ich język, kultura) jak i budujący ją pejzaż językowy. Użytkownicy przestrzeni i pejzaż językowy tworzą razem język miasta.

\section{Wizerunek miasta}

Kształtowanie wizerunku miasta jest procesem długim i złożonym. Wizerunek powstaje na podstawie tego, co użytkownicy przestrzeni zaobserwują, na podstawie informacji, które docierają do nich z kampanii promocyjnych, jak i informacji płynących z przestrzeni (np. z pejzażu językowego). W badaniach nad wizerunkiem miasta wyodrębniono również tzw. „komponenty afektywne i kognitywne” (Dudek-Mańkowska, 2011: 46, za Lynch, 1960). Pierwsze dotyczące uczuć, emocji - związane są z tym, jak odbieramy miasto - „są to wyobrażenia miasta, subiektywne wrażenia, czasem uprzedzenia, a nawet obawy" (ibid.). Komponenty kognitywne natomiast (inaczej poznawcze) „odnoszą się do wiedzy na temat miejsca - są to m.in. opinie na temat warunków życia w mieście" (ibid.). Wizerunek miasta bardzo często definiuje się więc jako: „całokształt subiektywnych wyobrażeń rzeczywistości, które wytworzyły się w umysłach ludzkich jako efekt percepcji, oddziaływania środków masowego przekazu i nieformalnych przekazów informacyjnych" (Rurański i Niemczyk, 2013: 68). W analizie wizerunku należy pamiętać, iż każdy odbiorca miasta może zbudować nieco inny obraz danego ośrodka, obraz ten ulega przemianom i ma złożony charakter, gdyż opiera się na indywidualnej opinii każdego uczestnika przestrzeni miejskiej. Ukształtowanie danego wizerunku wymaga także czasu (Szromnik, 1997). W tworzeniu wizerunku miasta istotne jest to, co myślą o mieście jego użytkownicy, jaki obraz miasta powstaje w ich umysłach. Jeśli przyjmiemy definicję Kotlera i in. (1999: 141), wówczas wizerunek można określić jako ,[...] sumę wierzeń, idei i wrażeń, jakie ludzie mają na temat miasta". Warto wspomnieć, że w pojęciu wizerunku kryje się cały zbiór informacji na temat danego miejsca, które trafiają do odbiorców poprzez indywidualne subiektywne doświadczenie, często bezpośrednie. Stworzony na ich podstawie obraz miasta jest to o wiele bardziej trwały niż w przypadku konieczności zbierania obiektywnych informacji z różnych źródeł (Grzyś, 2017).

Każde miasto posiada swój własny określony wizerunek, gdyż jak podaje Stanisław Puppel (2016: 109) „wizerunek stanowi nieodłączną część wszelkiej ziemskiej cielesności (bytowości fizycznej/organizmalnej)”. Tym samym wizerunek wiąże się „Zarówno z 'wyglądem' jak i 'oglądem', a więc wyposażeniem jej w różnorakie atrybuty nadawczo-odbiorcze” (2016: 109). W kontekście miasta, to przestrzeń 
miejska komunikuje swoim użytkownikom swój wygląd (złożony z różnorakich elementów, np. architektura, infrastruktura, organizacja, parki, ale również kompozycja społeczno-kulturowa, czyli to kogo możemy spotkać w danej przestrzeni, jakie języki możemy usłyszeć), użytkownicy natomiast odbierają/oglądają przestrzeń poprzez jej cechy charakterystyczne. Większość miast dąży do wytwarzania wizerunku, tworzenia „oglądu”, który będzie budował pozytywny jego obraz w odbiorcach. Skoro pojęcie wizerunku łączy w sobie wygląd i ogląd, można owe pojęcie odnieść do twarzy - części ciała człowieka, która stanowi podstawę jego całościowego wizerunku. Wizerunek miasta - to co widzi i odbiera uczestnik przestrzeni miejskiej - jest w pewnym sensie twarzą tego miasta. Twarzą, na której malują się wszelakie doświadczenia, wydarzenia, historia, kultura, kompozycja społeczna. Istotną funkcję twarzy zaznacza m.in. Joanna Puppel (2016: 202), wskazując iż „twarz [...] w kulturze wizualnej pozostaje jednym z najważniejszych wskaźników komunikacyjnej, ale także i estetycznej, obecności człowieka w otwartej przestrzeni publicznej $[\ldots]$ "..

Istotnym zagadnieniem $\mathrm{w}$ kształtowaniu wizerunku miasta jest również tożsamość danego miejsca. Jej elementy w znaczący sposób przyczyniają się do wykreowania obrazu miasta.

\section{Tożsamość miasta}

Pojęcie tożsamości miasta stanowi jedno z kluczowych zagadnień w dyskusji dotyczącej tworzenia wizerunku miasta. Tożsamość jest o tyle istotna, gdyż miasta, szczególnie duże aglomeracje, o wiele szybciej i częściej podlegają globalnym trendom kulturowo-społecznym i tym samym są bardziej narażone na utratę swojej wyjątkowej tożsamości i charakteru. Tymczasem kreowanie wizerunku opiera się właśnie na wyrazistości. Często jednak okazuje się, że wraz z intensywnym procesem globalizacji w różnych sferach życia „coraz mniejsze znaczenie w kreowaniu wizerunku miasta odgrywają elementy wynikające z jego tożsamości” (Grzyś, 2017: 4). Dzieje się tak, iż elementy budujące tożsamość mogą wzbudzać negatywne skojarzenia i tym samym budować negatywny obraz danego miasta w umysłach odbiorców (np. problem miast poprzemysłowych) (ibid). Należy jednak pamiętać, jak podaje Grzyś (2017: 7), że ,pomijanie charakterystycznych dla miasta elementów tożsamości danej jednostki powoduje zaangażowanie w proces fikcjonalizacji, który zamiast działać na korzyść miasta, może całkowicie pozbawić je charakteru”.

Tożsamość jest pojęciem bardzo złożonym i definiowanym różnie $\mathrm{w}$ różnych dyscyplinach naukowych. Tożsamość miasta określa się m.in. jako ,[...] zbiór cech charakterystycznych, które wyróżniają miasto spośród innych i wyrażają się wszelkimi działaniami, jakie są podejmowane, tworząc jego swoistą osobowość i charakter" (Łuczak, 2005: 48). Tożsamość miasta dla niektórych badaczy, np. Mefferta 
(1989), stanowi fundament wizerunku miasta. Jest to podejście o tyle istotne, iż jak podaje Grzyś (2017:8, za Glińska, 2008: 3), miasto powinno opierać swój wizerunek na tożsamości, na czymś realnym, prawdziwym, tak żeby zbudować wiarygodny obraz. Tym samym można stwierdzić, że w kreowaniu wizerunku miasta nie chodzi o wytwarzanie tożsamości od nowa lecz sięganie do elementów tożsamości, które od lat stanowią jej fundament, np. kwestie historyczne czy społeczno-kulturowe. Takie, których nie można z dnia na dzień wykreować.

Według Mefferta (1989), tożsamość miasta składa się z trzech elementów: systemu identyfikacji wizualnej, systemu komunikacji oraz kultury miasta. System identyfikacji wizualnej obejmuje symbole związane $\mathrm{z}$ miastem, które pozwalają odróżnić dane miasto od innych. Są to np. flagi, herby, kolorystyka, z którą identyfikuje się miasto, piktogramy, logo. System komunikacji dotyczy komunikacji z mieszkańcami i osobami przyjezdnymi. Ostatni element w modelu Mefferta kulturę - Rurański i Niemczyk (2013: 69) opisują jako „zbiór wartości, norm, zwyczajów i tradycji, a także typowych zachowań i poglądów charakterystycznych dla danej społeczności”. Należy pamiętać, że jednym z kluczowych elementów tworzących tożsamość jest język, który w dobie globalizacji może być znaczącym wyróżnikiem wizerunku miasta. Tym samym warto przede wszystkim zwrócić uwagę na drugi element (system komunikacji), o czym wspomina Koszko (2018) podejmując próbę modyfikacji modelu Mefferta i zastępując ww. element pojęciem „pejzażu językowego".

\section{Język a tożsamość i wizerunek miasta - interakcyjność przestrzeni miejskiej}

W procesie definiowania wizerunku i tożsamości miasta często podaje się szereg istotnych cech, które są składowymi obydwóch zagadnień, m.in.: wierzenia, idee, wrażenia, zwyczaje, elementy materialne, zabytki, wydarzenia kulturalne, opinie itp. W odniesieniu do nich tworzy się często kampanie promocyjne. Niewiele natomiast mówi się o podstawowym narzędziu, wykorzystywanym m.in. w tych kampaniach, które jest kluczowym elementem $\mathrm{w}$ formowaniu owych wrażeń czy opinii - a mianowicie o języku.

W kreowaniu wizerunku język może pełnić następujące funkcje:

1) narzędzia używanego świadomie - oddziałującego bezpośrednio: wszelkie kampanie promocyjne - hasła, slogany promocyjne, ulotki etc.

2) narzędzia działającego podświadomie na odbiorcę - oddziałującego bezpośrednio, w sposób naturalny. W tym przypadku należy wziąć pod uwagę:

a) aspekty społeczno-kulturowe - sytuację językową w przestrzeni miejskiej (przestrzeń homogeniczna monolingwalna a przestrzeń plurilingwalna);

b) pejzaż językowy. 
W niniejszym opracowaniu przyjęto iż poprzez działania podświadome, poprzez kompozycję społeczno-kulturową i pejzaż językowy miasto może wytworzyć albo wizerunek miasta interakcyjnie otwartego albo miasta interakcyjnie ograniczonego (Ryc. 1).

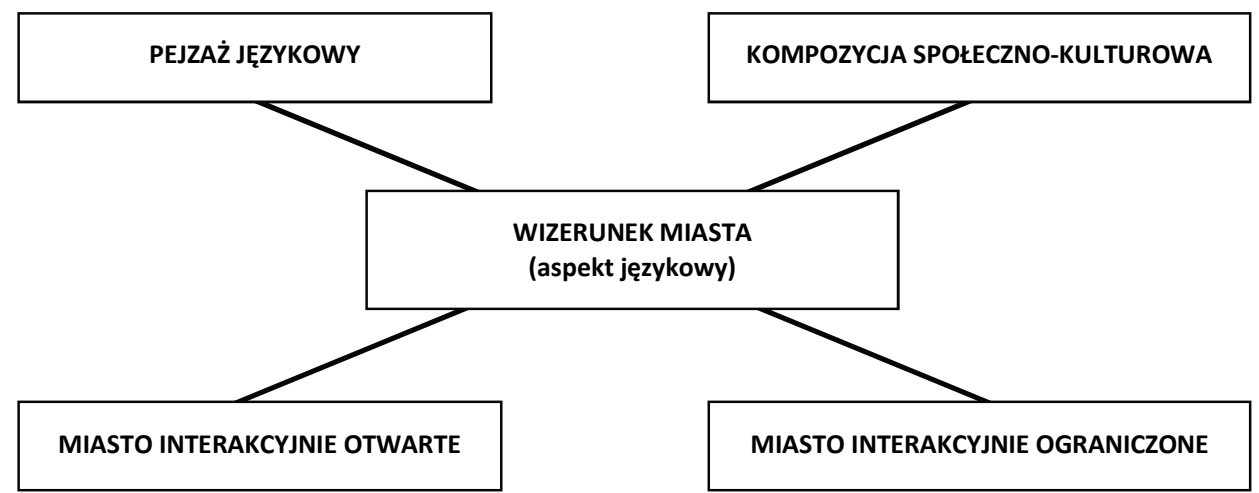

Ryc. 1. Znaczenie języka w tworzeniu wizerunku miasta (oprac. własne).

Jak podaje Słownik Języka Polskiego interakcja to „,wzajemne oddziaływanie na siebie osób, przedmiotów lub zjawisk” (ŹI 2). W kontekście niniejszych rozważań moglibyśmy więc mówić o mieście, w którym te oddziaływania są obecne albo jest ich niewiele lub w ogóle nie występują (choć raczej nie jest to możliwe). Interakcja, czyli owe oddziaływanie odbywa się m.in. za pomocą języka. Możemy także przyjąć, że interakcyjność miasta to przede wszystkim interakcyjność jego przestrzeni publicznej, gdyż często w niej dochodzi do kontaktów językowych.

\subsection{Kontekst społeczno-kulturowy}

Kontekst społeczno-kulturowy odnosi się przede wszystkim do charakterystyki etnolingwistycznej danego ośrodka miejskiego. Miasta stanowią ogromne skupiska ludności. W związku z tym mogą one charakteryzować się różnorodnością kulturowo-etniczno-językową. Są one również najczęściej wybierane przez imigrantów, którzy upatrują oni w nich szansę na nowe lepsze życie. Wraz z napływem imigrantów zmienia się również przestrzeń miejska (zob. m.in. Grześkowiak, 2010; Koszko, 2018) oraz sytuacja językowa miasta (zob. Szul, 2013: 65). Poza tym miasta to często duże ośrodki akademickie, przyciągające studentów z różnych krajów oraz są o wiele częściej odwiedzane przez turystów, gdyż posiadają bogate dziedzictwo kulturowe zarówno materialne jak i niematerialne. W związku z tym przestrzeń 
publiczna dużych aglomeracji miejskich będzie zazwyczaj bardziej żywa/aktywna i tym samym nacechowana językowo, gdyż będzie ona odzwierciedlała wspomniane trendy społeczno-kulturowe. Przykładem mogą być duże ośrodki jak Londyn, Berlin, Warszawa, Paryż, ale również mniejsze istotne miasta np. Poznań.

Należy pamiętać jednak, że w wielu krajach funkcjonuje jedynie kilka bardzo dużych ośrodków miejskich różnorodnych etnicznie, językowo i kulturowo. Pozostałe miasta są o wiele bardziej homogeniczne. Owa homogeniczność jest również zauważalna w języku obecnym w przestrzeni miejskiej.

Przy porównaniu dwóch miast np.: Poznania i Piławy Górnej (woj. dolnośląskie) (Tab. 1) można zauważyć, jak bardzo może różnić się przestrzeń miejska niewielkiego miasteczka w woj. dolnośląskiem, bez rozwiniętej turystyki, ze społecznością homogeniczną etnicznie i językowo od przestrzeni publicznej Poznania. Przestrzeń ta będzie bardziej nacechowana językowo, tzn. częściej będzie w niej można doświadczyć różnorodnych kontaktów językowych, gdyż w populacji notuje się pewną liczbę obcokrajowców (studenci lub osoby pracujące) oraz miasto jest odwiedzane przez turystów. W przypadku Piławy Górnej użytkownik nie może raczej oczekiwać kontaktów innych niż w języku rodzimym, języku polskim.

Tabela 1. Porównanie struktury ludności w Poznaniu i Piławie Górnej

\begin{tabular}{|l|r|c|}
\hline \multicolumn{1}{|c|}{ Dane rok 2017 } & Poznań & Pilawa Górna \\
\hline Liczba mieszkańców (zameldowanych) & 538633 & 6479 \\
\hline Os. niezameldowane szacunkowo (studenci, obcokrajowcy) & 132600 & brak danych \\
\hline Studenci obcokrajowcy & 5000 & - \\
\hline Obcokrajowcy z pozwoleniem na pobyt & 2700 & - \\
\hline Obcokrajowcy pracujący & 42000 & - \\
\hline
\end{tabular}

Źródło: na podstawie danych z http://www.poznan.pl/mim/info/news/liczba-ludnosci-w-poznaniu,121374.html oraz https://stat.gov.pl/vademecum/vademecum_dolnoslaskie/portrety_gmin/powiat_dzierzoniowski/gmina_m_pila wa_gorna.pdf

Miasta różnorodne etnicznie i kulturowo i tym samym językowo, zazwyczaj stwarzają wizerunek miast kosmopolitycznych, w których tygiel kulturowy odzwierciedlony jest właśnie w języku. Londyn, w którym na co dzień mówi się ponad 250 językami (zob. Baker i Eversley, 2000), na wielokulturowości i wielojęzyczności zbudował bardzo atrakcyjny wizerunek i jest jednym z najchętniej odwiedzanych miast na świecie. Interakcyjnie jest to miasto bardzo otwarte. Przebywając chwilowo bądź bytując na co dzień w takich aglomeracjach, nie sposób odseparować się od języków mniejszości, jak również języka dominującego, gdyż nieustannie wchodzimy w interakcje z innymi użytkownikami przestrzeni. Warto tym samym zauważyć, że to właśnie kontakty $\mathrm{z}$ innymi (kontakty językowe) trwale zapisują się $\mathrm{w}$ tworzą- 
cym się w naszych umysłach wizerunku miasta. Użytkownicy przestrzeni (wraz z językiem, którym się posługują) stanowią więc często jeden z kluczowych elementów budujących obraz danej aglomeracji.

\subsection{Pejzaż językowy}

Drugim istotnym elementem kształtującym interakcyjność miasta jest pejzaż językowy. Pojęcie to dotyczy najczęściej języka obecnego na znakach drogowych, tablicach z nazwami ulic, tablicach ogłoszeń, tablicach pamiątkowych lub informacyjnych umieszczonych w przestrzeni publicznej albo przez instytucje oficjalne (tzw. oznakowanie „top-down”) lub osoby prywatne (tzw. oznakowanie „,bottom-up”) (zob. m.in. Spolsky i Cooper, 1991; Landry i Bourhis, 1997; Ben Rafael i in., 2006; Görter, 2006; Shohamy i Waksman, 2009; Grześkowiak, 2010; Budarina, 2017).

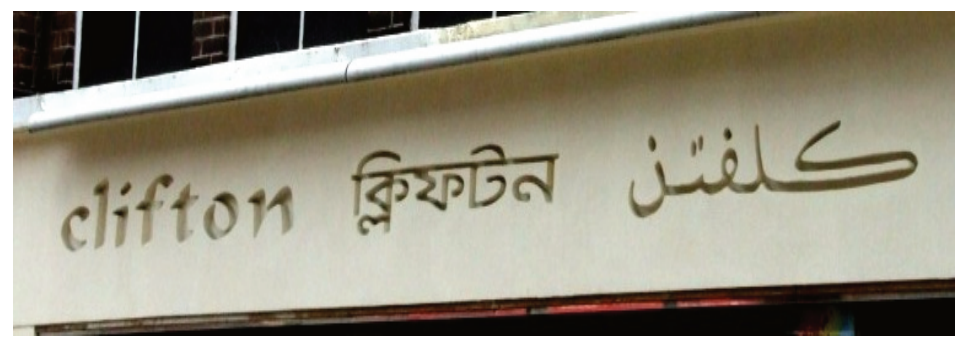

Fot. 1. Tablica wielojęzyczna (oznakowanie „,bottom-up”) (fot. MK).

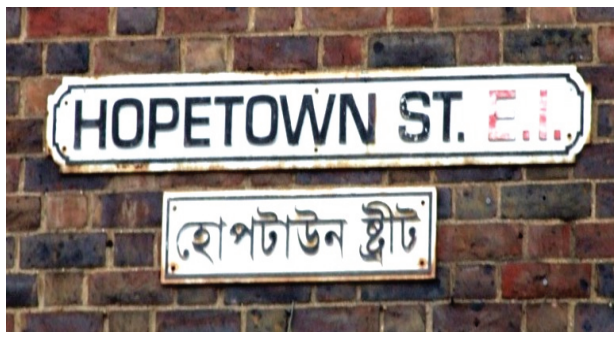

Fot. 2. Dwujęzyczna tablica z nazwą ulicy w Londynie, Bangla Town (oznakowanie „top-down”) (fot. MK).

Pejzaż językowy można analizować m.in. pod względem współistnienia języków, relacji między językami i tym samym stworzyć obraz społeczno-językowokulturowy danego miejsca. Analizy oznakowania miasta pod kątem językowym zazwyczaj rysują obraz miast wielojęzycznych z różnorodnością kultur, zwyczajów z mocno zróżnicowaną przestrzenią zrytualizowaną. Użytkownik takowej przestrze- 
ni bądź osoba przyjezdna na podstawie wielojęzycznego oznakowania buduje sobie obraz miasta kulturowo i językowo bogatego. Dla osoby przyjezdnej/turysty oznakowanie w dwóch lub większej liczbie języków jest zarówno pewnego rodzaju atrakcją, jak również swoistego rodzaju udogodnieniem przy poruszaniu się w początkowo być może obcej mu przestrzeni miejskiej. Jest to również wyraźny sygnał, że miasto jest otwarte interakcyjnie, chce komunikować się ze swoim użytkownikiem.

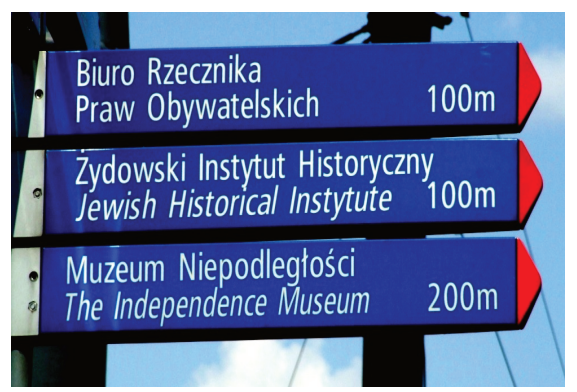

Fot. 3. Tablice informacyjne/kierunkowe w Warszawie (oznakowanie „top-down”) (fot. MK).

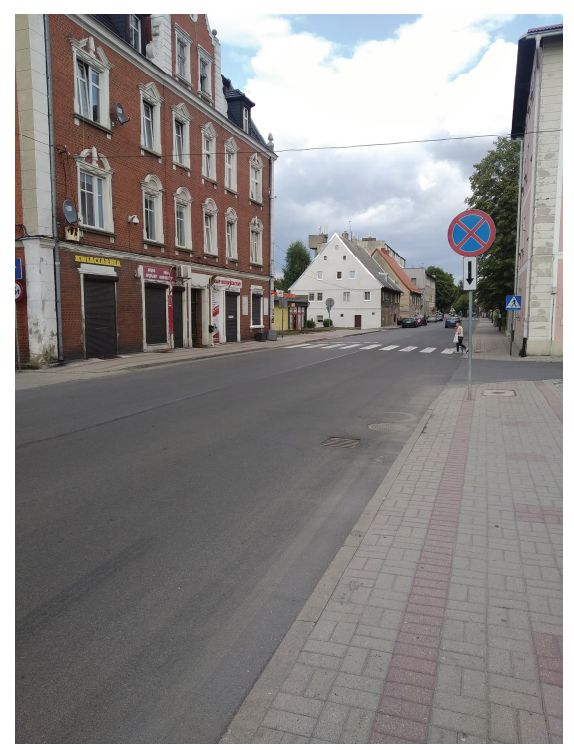

Fot. 4. Piława Górna -ul. Piastowska (główna ulica miasta) - pojedyncze oznakowanie prywatne (,,bottom-up”) - nazwy sklepów (fot. MK).

Język jest tutaj kluczowym elementem tworzącym wizerunek miasta przyjaznego, otwartego komunikacyjnie. Warto jednak zaznaczyć, że nie wszystkie miasta mają tak bogaty pejzaż językowy. W każdym mieście, małym czy dużym pojawia 
się oznakowanie. Jednak w przypadku niewielkich aglomeracji oznakowanie jest o wiele mniej zróżnicowane (także językowo) oraz jest go znacznie mniej. Przestrzeń taka ma nieco inny charakter i pejzaż językowy nie będzie w niej pełnił aż tak istotnej roli komunikacyjnej. W tym przypadku miasto dla mieszkańców wizerunkowo się nie zmieni, natomiast jeśli pojawią się w nim osoby przyjezdne nieznające języka dominującego, wówczas mogą one czuć się zagubione, gdyż zrozumienie oznakowania z przekazem werbalnym-pisanym może być niemożliwe. Wówczas mogą one zbudować mniej pozytywny wizerunek takiego miejsca.

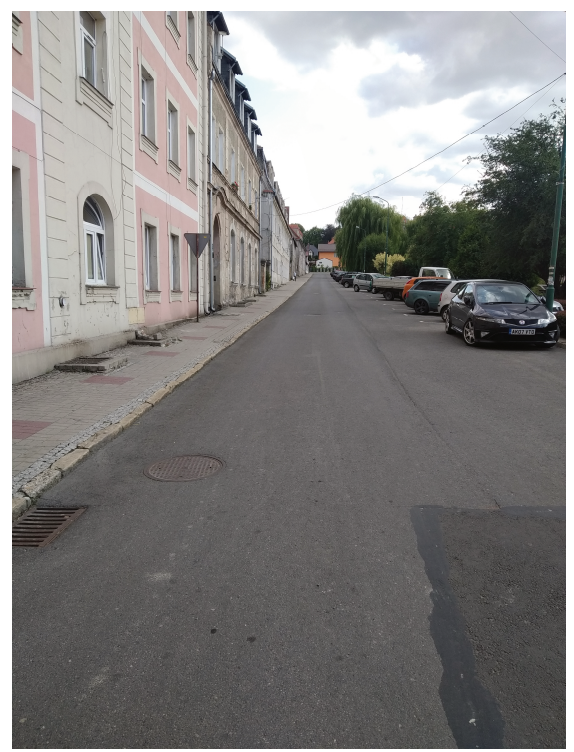

Fot. 5. Piława Górna. Ulica przy głównym placu, Plac Piastów Śląskich; brak oznakowania (fot. MK).

Pejzaż językowy odgrywa istotną rolę nie tylko w kontekście zagadnień dotyczących mono i plurilingwalizmu czy współistnienia języków w przestrzeni miejskiej. Można go również analizować w kontekście funkcji jaką spełnia np. w komunikacji pomiędzy miastem - jego przestrzenią - a jego użytkownikami. Pejzaż językowy bowiem, to również wszelkie tablice informacyjne, jedno- lub wielojęzyczne. Przestrzeń językowa/informacyjna dużych miast jest zazwyczaj bardzo urozmaicona $\mathrm{i}$ bogata $\mathrm{w}$ ten rodzaj przekazu. Jednym z przykładów są tablice nawiązujące do historii lub ważnych wydarzeń historycznych danego miasta (zob. Koszko, 2013). Tak skonstruowany pejzaż językowy pozwala stworzyć w umysłach odbiorców obraz miasta sprzed lat, odtworzyć zarys wydarzeń historycznych, poznać architekturę jak również kompozycję społeczno-kulturową danego miejsca. Staje się to możliwe dzięki opisom umieszczonym na tablicach. 


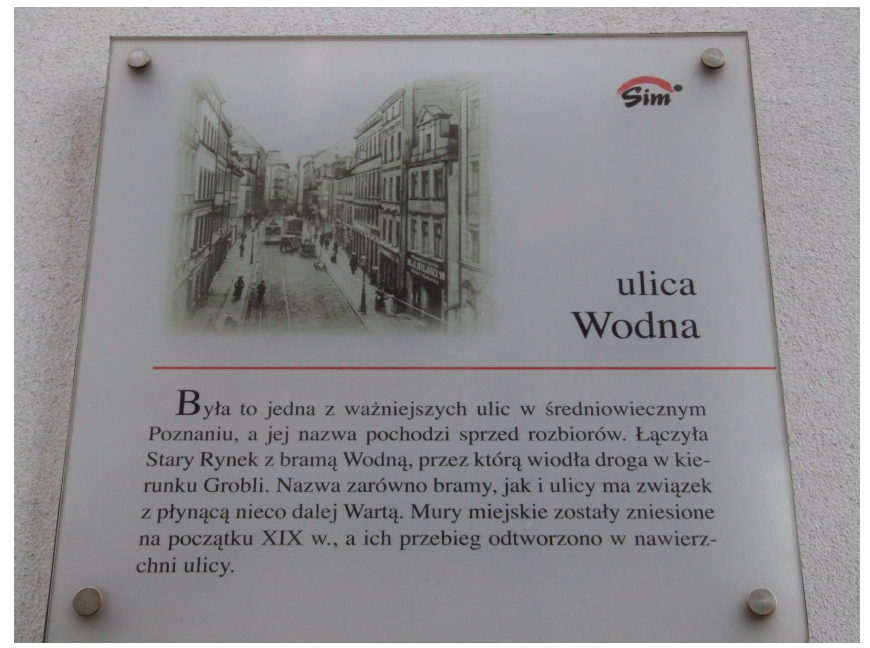

Fot. 6. Tablica informacyjna na ścianie budynku przy ul. Wodnej w Poznaniu. Zawiera krótką notkę opisującą historię ulicy, pochodzenie nazwy (fot. MK).

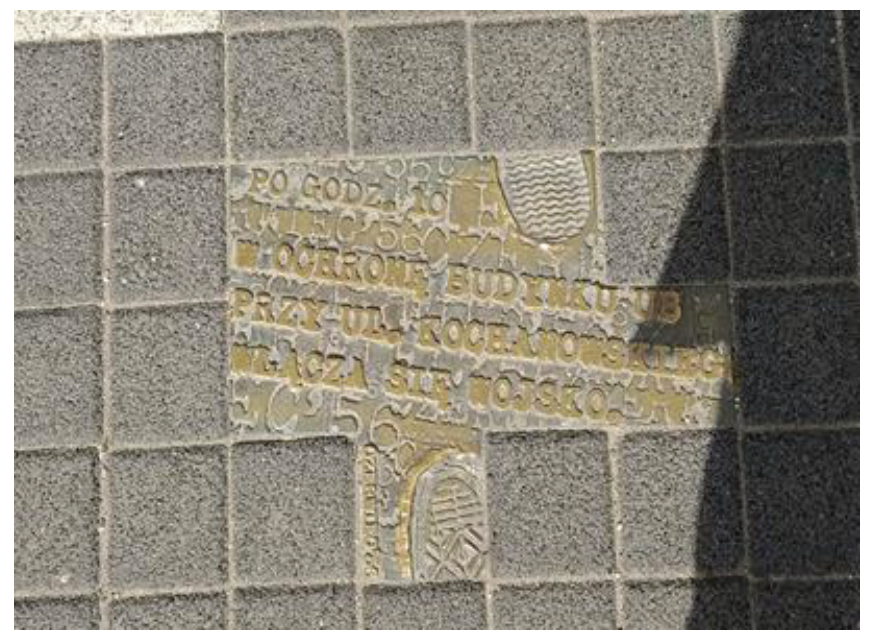

Fot. 7. Napis umieszczony w kostce chodnikowej na ul. Św. Marcin w Poznaniu. „Po godz. 10 w ochronę budynku UB przy ul. Kochanowskiego włącza się wojsko/ WIEC '56". Płyta ta nawiązuje do wydarzeń mających miejsce w Poznaniu w czerwcu 1956 roku (fot. MK).

Język jest więc nośnikiem kultury. Jako główne narzędzie komunikacyjne jest niezbędny w tworzeniu wizerunku. Podczas kontaktu z pejzażem językowym często nieświadomie tworzy się w naszych umysłach obraz miasta $\mathrm{i}$ jest on zazwyczaj bardzo trwały, gdyż poznawanie przez doświadczanie jest jednym z najlepszych sposobów zapamiętywania informacji. 


\section{Wnioski - wizerunek a interakcyjność przestrzeni}

W niniejszym opracowaniu zaproponowano podział na miasta interakcyjnie otwarte oraz miasta interakcyjnie ograniczone. Interakcyjność nie dotyczy jednak w tym przypadku jedynie kontaktów między ludźmi, ale również kontaktu między przestrzenią a jej użytkownikami. Język może odzwierciedlać kompozycję społeczno-kulturową miasta oraz często jest nośnikiem informacji o danym miejscu.

W mieście interakcyjnie otwartym przestrzeń jest żywa/aktywna i nacechowana językowo. Oznacza to, że nieustannie wysyła ona informacje do swoich użytkowników poprzez umieszczone w niej różnorakie przekazy (pejzaż językowy). Co więcej w mieście interakcyjnie otwartym rozwija się różnorodność językowa, a współistniejące języki naturalne tworzą swoisty charakter miejsca. Przestrzeń taka, otwarta, zachęca do interakcji. Miasto interakcyjnie otwarte jest również bardziej czytelne nie tylko dla mieszkańców, ale również dla osób przyjezdnych, gdyż zawiera m.in. informacje ułatwiające poruszanie się $\mathrm{w}$ obcej przestrzeni. W mieście interakcyjnie ograniczonym przestrzeń może być opisana jako bierna, często uboga językowo. Tym samym można stwierdzić, że może być ona interakcyjnie mniej rozwinięta. Sytuacja ta powstaje w wyniku homogenicznej kompozycji społeczno-kulturowej i tym samym językowej oraz słabo rozwiniętego pejzażu językowego (Ryc. 2).

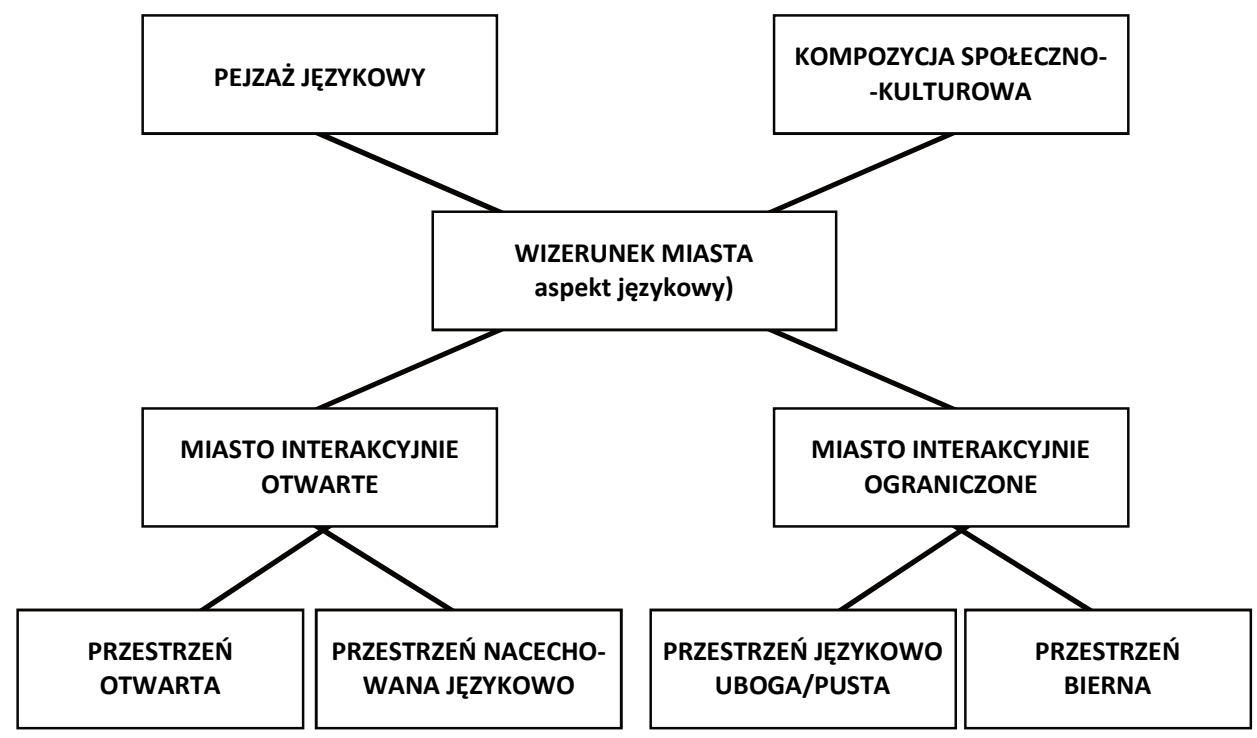

Ryc. 2. Wizerunek miasta w odniesieniu do interakcyjności jego przestrzeni - podsumowanie (oprac. własne). 


\section{Bibliografia}

Altkorn, J. 1999. Wizualizacja firmy. Kraków: Wydawnictwo AE w Krakowie.

Baker, P. i J. Eversley 2000. Multilingual capital. London: Battlebridge.

Ben Rafael, E., Shohamy, E., Amara, M.H. i N. Trumper-Hecht. 2006. „Linguistic landscape as symbolic construction of the public space: the case of Israel". International Journal of Multilingualism 3.1. 7-30.

Budarina, L. 2017. „Cosmopolitan Berlin? Interpreting the linguistic landscape of a cosmopolitan city”. Scripta Neophilologica Posnaniensia XVII. 77-88.

Dudek-Mańkowska, S. 2011. „Koncepcja wizerunku miasta”. W zbiorze: Grzegorczyk, A. i A. Kochaniec. (red.). 2011. Kreowanie wizerunku miast. Warszawa: Wyższa Szkoła Promocji. 42-67.

Glińska, E. 2008. Zarządzanie procesem ksztaltowania wizerunku miasta wśród jego mieszkańców na przykladzie Zambrowa. Toruń: Wydawnictwo Adam Marszałek.

Görter, D. (red.). 2006. Linguistic landscape. A new approach to multilingualism. Clevedon: Multilingual Matters.

Grześkowiak, M. 2010. Trans-city or Inter-city? The co-existence of majority and minority languages in the urban space: a comparative case study of London and Warsaw linguistic landscapes. Poznań: Katedra Ekokomunikacji UAM.

Grzyś, P. 2017. „Wizerunek miasta a jego tożsamość - współczesne zależności”. Architects 2.50. 3-13.

Koszko, M. 2018. „Redefining the image of the contemporary city - changes in linguistic and cultural realms - preliminary remarks". Scripta Neophilologica Posnaniensia XVIII. 43-54.

Kotler, P., Asplun, C., Rein, I. i D. Haider. 1999. Marketing places Europe. How to attract investments, industries, residents and visitors to cities, communities, regions and nations in Europe. London: Pearson Education.

Landry, R. i R.Y. Bourhis 1997. „Linguistic landscape and ethnolinguistic vitality: an empirical study”. Journal of Language and Social Psychology 16.1. 23-49.

Lynch, K. 1960. Image of the city. Cambridge-London: MIT Press.

Łuczak, A. 2005. „Istota tożsamości miasta/Image of the city and its identity - contemporary relations”. Samorzad terytorialny 1. 46-53.

Meffert, H. 1989. „Stadtemarketing - Plicht oder Kur?”. Planung und Analyse 8. 273-280.

Puppel, J. 2016. „Wskaźnikowość twarzy ludzkiej: krótki przegląd problematyki”. Scripta Neophilologica Posnaniensia XVII. 201-206.

Puppel, S. 2016. „Kuźnia Hefajstosa czyli krótki zarys teorii wizerunku w komunikacji człowieka”. Scripta Neophilologica Posnaniensia XVII. 513-522.

Rurański, M. i J. Niemczyk 2013. „Współczesne instrumenty kształtowania wizerunku miasta na przykładzie Wrocławia". Studia Miejskie 11. 67-78.

Shohamy, E. i S. Waksman. 2009. „Linguistic landscape as an ecological arena: modalities, meanings, negotiations, education". W zbiorze: Shohamy, E. i D. Görter. (red.). Linguistic landscape: expanding the scenery. New York: Routledge. 313-331.

Spolsky, B. i R.L. Cooper. 1991. The languages of Jerusalem. New York: Oxford University Press.

Stanowicka, A. 2015. „Planowanie strategii kształtowania wizerunku miasta/Planning a strategy to create the city's image". Zarzadzanie. Teoria i Praktyka. 14 (4). 19-25.

Szromnik, A. 1997. Marketing terytorialny. Miasto i region na rynku. Gdańsk: Walters Kluwer.

Szul, R. 2013. „Miasto a język. Rola miast w kształtowaniu sytuacji językowej”. Studia z Geografii Politycznej i Historycznej 2. 63-85. 


\section{Źródla internetowe}

ŹI 1:

https://www.un.org/development/desa/en/news/population/2018-revision-of-world-urbanization-pros pects.html

ŹI 2:

PWN https://sjp.pwn.pl/slowniki/interakcja.html)

ŹI 3:

http://www.poznan.pl/mim/info/news/liczba-ludnosci-w-poznaniu,121374.html

ŹI 4:

https://stat.gov.pl/vademecum/vademecum_dolnoslaskie/portrety_gmin/powiat_dzierzoniowski/gmi na_m_pilawa_gorna.pdf 